\title{
直達式骨折整復支援装置を用いた整復動作に関する研究 \\ Study on Fracture Reduction Assistance Computerized Robot
}

O加門 大和 ${ }^{1}$, 鄭 常賢 ${ }^{2}$, 廖 洪恩 ${ }^{2}$ ，小林 英津子 ${ }^{1}$ ，光石 衛 ${ }^{1}$ ，中島 義和 ${ }^{1}$ ，小山 毅4, 菅野 伸彦 ${ }^{4}$,

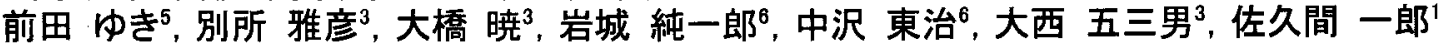

東京大学大学院 [1. 工学系研究科，2. 新領域創成科学研究科，3. 医学系研究科]，

4. 大阪大学大学院医学系研究科，5. 大阪南医療センター，6. THK

OH.Kamon ${ }^{1}$, S.Jhoung ${ }^{2}$, H.Liao' ${ }^{2}$, E.Kobayashi', M.Mitsuishi' ${ }^{1}$, Y.Nakajima ${ }^{1}$, T.Koyama ${ }^{4}$, N.Sugano ${ }^{4}$,

Y.Maeda ${ }^{5}$, M.Bessho $^{3}$, S.Ohashi ${ }^{3}$, J.Iwaki ${ }^{6}$, T.Nakazawa ${ }^{6}$, I.Ohnishi ${ }^{3}$, I.Sakuma ${ }^{1}$

[1. Graduate School of Engineering, 2. Graduate School of Frontier Sciences,

3. Graduate School of Medicine], the University of Tokyo,

4. Graduate School of Medicine, Osaka University,

5. National Organization Osaka Minami Medical Center, 6. THK

\section{1. はじめに}

大腿骨頚部骨折は高齢者に起こりやすい骨折で, 社会の高齢 化の進行に伴って患者も増加すると予想される.手術では遠位 骨片を牽引・回旋しながら位置決めし, 骨折部位をピソなどで固 定する. しかし大腿骨の周辺の筋は牽引を妨げるので, 大きな力 が要る. また, 骨折部位の仮骨形成を早めるためには, 骨片間距 離を $2[\mathrm{~mm}], 2\left[\right.$ degrees]以内に収める必要がある. ${ }^{1)}$ しかも, X線 透視下で 2 次元画像による位置決めを行うため, 熟練した技術が 必要である. 術者が受けるX線も問題である.

この問題に対し, 我々はロボットで㲤引を補助し, 医師の負担 を隇らす。このロボットに, 骨軸に沿うようにロボットの駆動方向を 拘束するといら, 拘束パワーアシスト(Fixed Power Assistance: FPA)の実装した骨折整復支援装置(Fig. 1)の開発を行っている. 本研究では, 直達率引骨折整復支援装置を用いた拘束パワーア シストによる骨折整復動作の動作精度を評価した。

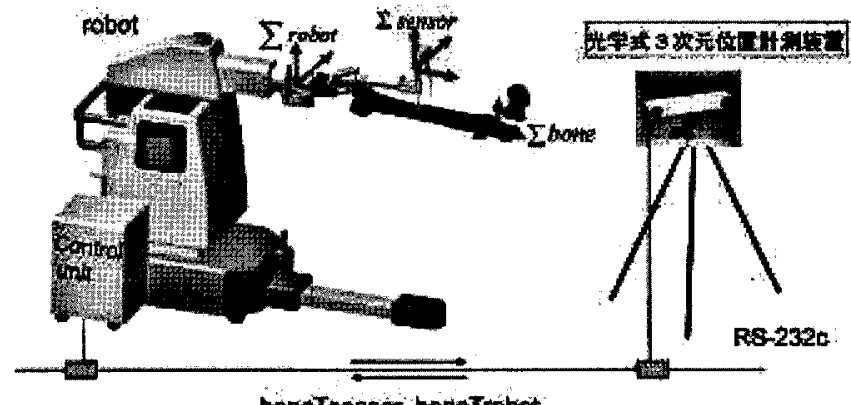

Fig. 1 骨折整復支援装置(ロボット)とシステム構成

\section{2. システム構成}

システムの流れを Fig.2 に示寸. 光学式三次元位置計測装置 を使用してロボッ卜座標・カセンサ座標・骨座標の位置を計測し， カセンサと骨，ロボットと骨の対応関係を算出する. カセンサに入 力した力情報(術者の力)を骨座標での力情報に変換し, 骨片を 移動させない方向 (例えば骨軸に沿わない衰引・回旋方向等)の 力成分をぜロに設定する. その結果得られた力ベタトル力向に骨 片が移動するように目標位置を定め, その位置へ駆動するため のロボットの逆運動学計算を行い, 速度指令を生成する。

\section{3. 実験および結果}

骨片の位置決めは率引動作と回旋動作の2つに分けて行われ ているので, それぞれの動作について精度評価を行った. 計測 には光学式三次元位置計測装置を用いた.

㲤引動作は骨の長軸方向に星引した。骨の長軸ベタトルと計 測点から得られる近似直線ベクトルがなす角を評価した. 要求仕

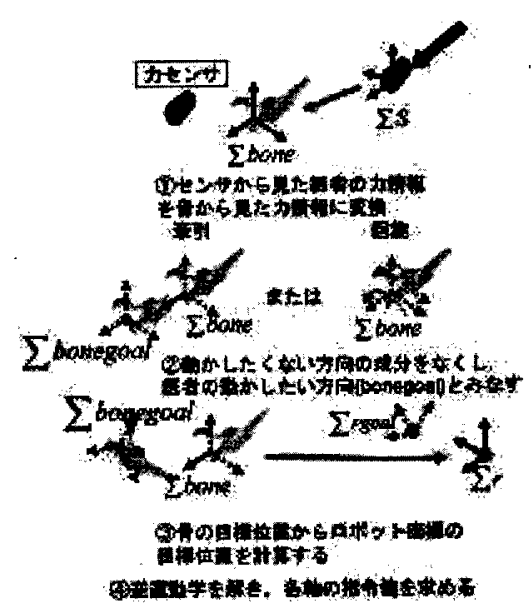

Fig. 2 FPA の駆動方式

様が 2[degrees]に対して 0.25[degrees]という高精度で牽引でき た.

回旋動作は骨が 0.2[deg/s]で回旋するように各軸モー夕に指 令した. 骨座標の各軸周りにそれぞれ回旋し，骨の位置の変化 量を評価した. 要求仕様が $2[\mathrm{~mm}]$ であるのに対し, 平均誤差は $5.9[\mathrm{~mm}]$ と大きな值となった。これは，ロボットに機構的なガタが あることが原因と考えられる.

\section{4. まとめ}

FPA の精度評価を行い, 牽引動作については目的とする精度 での拘束が可能であったが, 回旋動作については装置のガタや 指令速度通れ等が原因となり，必要となる拘束精度を実現するこ とはできなかった，今後は装置のガ夕を修理して回旋動作の精度 を高くし，モデル脚で FPAの有效性を評価する予定である.

\section{5. 謝辞}

本研究の一部は)愿生労働科学研究費補助金 (医療機器開発 推進研究事業)「低侵襲・高精度骨折整復・治療支援システムの 開発 (H20-ナ) 一般-002)」, 厚生労㗢科学研究費補助金(医療 機器開発推進研究事業: 身休機能解析・補助・代替機器開発研 究事業)「高齢者の大腿骨頝部骨折等の治療を支援する高精度 手術支援システム(H17-フイジー一般-007)」によるものである.

\section{6. 参考文献}

1）山路哲生, Dynamization の仮骨形成促進. 整形·荻害外 科 $2002 ; \operatorname{Vol} 45$ (No4) : p305-310. 